\title{
Imaginario Social: Una aproximación desde la obra de Michel Maffesoli.
}

\section{Social Imaginary: An approach from Michel Maffesoli's work}

\author{
Nizaiá Cassián, Ma. Gisela Escobar, Ricardo Espinoza, Raúl García, Martín \\ Holzknecht y Carolina Jiménez \\ Universitat Autònoma de Barcelona \\ nizaiacass@hotmail.com ; mariagisela2000@yahoo.es ; ricardoespinoza76@yahoo.es; \\ raulgarciar@gmail.com; martinholz@hotmail.com; carojigo@hotmail.com.
}

\section{Resumen}

En este texto presentamos una revisión, -a modo de ejercicio de reflexión colectiva-, de la extensa producción bibliográfica de Michel Maffesoli, buscando articular desde los supuestos presentes en su obra, la noción de imaginario social. Para comprender el contexto de producción de este sociólogo francés, hemos comenzado por hacer una breve revisión de sus principales trabajos e influencias teóricas. Posteriormente hemos centrado la reflexión sobre sus textos fundamentales: El conocimiento ordinario, La orgía, El tiempo de las tribus, Elogio de la razón sensible y El instante eterno. Finalmente, nos aproximamos a la intersección de su obra con el imaginario social de acuerdo a cuatro categorías temáticas propuestas por Enrique Carretero (2003): el significado de la utopía, la problemática en torno a la modernidad, la integración simbólica del neotribalismo y la legitimidad del orden social.

Palabras clave: Maffesoli; Imaginario social; Postmodernidad.

\section{Abstract}

In the following text we display a review, -a sort of collective reflection exercise-, regarding the extensive bibliographic production of Michel Maffesoli, trying to articulate the notion of social imaginary departing from the suppositions present in Maffesoli's work. In order to understand the production context of this French sociologist, we began by a brief review of his main work as well as other theoretical influences. Afterwards, his fundamental texts are the subject to a reflection: Ordinary Knowledge, The orgy, The Time of the Tribes, Praise of a Sensible Reason, and The Eternal Instant. Finally, several elements studied were integrated in an approach to the notion of social imaginary, facing four thematic categories following Enrique Carretero's (2003) proposals: utopia's meaning, problems concerning modernity, symbolic integration of neotribalism, and the legitimacy of social order.

Keywords:

Maffesoli;

Social imaginary;

Postmodernism.

\section{I.- MAFFESOLI Y SU TIEMPO}

El imaginario social fundamenta toda sociedad. Las diferentes posturas a lo largo de la historia en lo concerniente a la imagen, cual hilo conductor, evidencian un miedo a lo sensible que se opone a la pura razón. A pesar de su apariencia, la imagen es aquello que 
describe lo real actuando en la vida social. El mundo "imaginal" constituye, de hecho, la post-modernidad: es la "cosa mental" que refuerza el vínculo social.

Michel Maffesoli (2003) El imaginario social. Revista Anthropos.

Michel Maffesoli estudió filosofía y sociología en Lyon, logrando su maestría con un trabajo acerca de la técnica en Marx y Heidegger. A comienzos de la década de los setenta se traslada a Grenoble, en donde toma contacto con Gilbert Dürand, quien dirige sus tesis de doctorado y le introduce en la temática de lo imaginario.

En sus primeras obras, sus ideas, se centran en la revisión de los pilares teóricos del marxismo frankfurtiano ligado a una crítica de la lógica tecno-productiva y asepsia social instaurada por la modernidad, al mismo tiempo que comienza a vislumbrar la importancia de lo imaginario como germen sobre el que necesariamente descansa la utopía. Producción que facilita la contemplación de la cotidianidad como invención, creatividad, y especialmente, como espacio de resistencia a todo tipo de coacción o imposición externa.

En 1981 es nombrado profesor titular de la Universidad de La Sorbonne en París y funda, junto con el antropólogo Georges Balandier, el Centro de Estudios sobre lo Actual y lo Cotidiano (París), buscando aplicar la noción de imaginario a ámbitos concretos de la vida cotidiana. Asimismo funda el Centro de Investigaciones sobre lo Imaginario (Grenoble) e imparte clases en La Sorbonne, estando a su cargo la Cátedra sobre el sociólogo Emile Durkheim.

En sus posteriores obras, indaga en los aspectos propiamente irracionales de la existencia social que fueron eclipsados y doblegados por el modelo de racionalidad impuesto por la modernidad. Es así que fruto de la preocupación teórica por desentrañar la lógica de lo cotidiano busca fundamentar en sus siguientes trabajos una verdadera epistemología de la cotidianidad, amparándose para ello en el formismo Simmeliano. Aboga por una valoración del componente pasional, lúdico y sensible, inexistente en la tradición sociológica.

Para finales de los 80', y luego de publicar el tiempo de las tribus, su pensamiento comienza a afianzarse en el panorama académico. Emerge en su trabajo la idea de tribalismo como determinante de la cultura, apostando por una comprensión de la sociedad en base a una fragmentaria gama de microcomunidades articuladas en torno a sentimentos y experiencias conjuntas que descansarían sobre una particular forma de socialidad.

En ese sentido, el análisis de Maffesoli sobre la postmodernidad gira en torno a la idea de la vuelta a lo arcaico, bajo unas novedosas figuraciones que estarían expresando un reencantamiento del mundo. Asimismo, el declive de los pilares básicos sobre los que se configuraría la modernidad, donde las categorías de razón, individuo y progreso, estarían dando paso a una nueva arquitectura cultural cuyo esclarecimiento constituiría el verdadero reto intelectual de nuestra época.

Entre las fuentes e influencias de su trabajo, se pueden distinguir tanto a los filósofos griegos como a los autores clásicos de la sociología (Chuaqui, Laura. 2004). Entre los primeros, Platón es señalado por Maffesoli al aludir las elaboraciones teóricas de cada momento del devenir social.

Para el autor, cada época y cada civilización ha generado una reflexión más o menos abstracta y desde Platón hasta Augusto Comte, pasando por Santo Tomás de Aquino, podrían multiplicarse los 
grandes sistemas interpretativos que han marcado los tiempos y las generaciones siguientes. Sistemas, que en tanto dimensión mitológica, mas allá de su cientificidad propia, han estado inyectados de ideología que los seres humanos descubrimos o reconocemos a destiempo.

Otro filósofo griego que constituye parte de las fuentes teóricas de Maffesoli es Aristóteles, a quien se puede identificar cuando plantea la idea de "hábito". En ese sentido, el habitus para Aristóteles es ante todo un "arreglo" entre quien tiene un atuendo y el atuendo que éste tiene, pero este arreglo no tiene nada de factual; es esencial para la existencia, el habitus pues es una cualidad en todo el sentido de la palabra, la cual efectúa o negocia la relación con el mundo.

Este habitus, que sirve para comprender la acción y el pensamiento del hombre en el espacio siempre ha sido la base del concepto de estilo, el cual se expresa concretamente en el tipo de indumentaria, de gobierno, comunicación y circulación diarias. En Aristóteles tenemos bien dirimido este habitus de la cultura, que interesa de sobremanera al sociólogo francés.

Con respecto a las fuentes de los sociólogos clásicos en los cuales se inspira Maffesoli, se pueden señalar algunos aportes de George Simmel, Max Weber y principalmente Durkheim. De George Simmel, Maffesoli se inspira cuando se refiere a los conceptos de "estilización" y de "formismo". Con el primero de ellos, "estilización", Maffesoli se manifiesta de acuerdo con Simmel en el sentido de que todo trabajo sociológico debe poseer además una buena escritura y un buen estilo.

Maffesoli utiliza la noción de formismo como elemento clarificador de la efervescente vuelta a la sensibilidad propia de la postmodernidad. Para Enrique Carretero (2003a) la perspectiva sociológica formista en Maffesoli sería aquella que permitiese mostrar la relevancia de distintas formas de coparticipación comunitaria movidas por una actitud sentimental. En efecto, el autorreconocimiento es el móvil básico que preside la lógica de lo social, del cual la forma es su fundamento; careciendo de toda dimensión de proyecto o finalidad histórica y fijando su atención en la experiencia presente. En ese sentido, el concepto de formismo no permite el contrasentido que habitualmente provocaba la idea de "forma". También en este caso las raíces de este concepto pueden remontarse a la tradición aristotélica-escolástica, donde se le denomina "causa formal" o "forma sustancial".

De Max Weber, Maffesoli toma las ideas expuestas en "El sabio y la política" planteando la diferencia entre que lo que es legítimo para el funcionario de la autoridad o el político, es perjudicial para el pensador. Así lo que "es" tiene prioridad por sobre lo que "debe ser". Esta es la irresponsabilidad del intelectual: no tiene que responder por los demás, tampoco tiene que responder de los demás: tiene que escucharlos. Es la eterna relación con la alteridad que, a lo largo de los tiempos, se expresa por medio de lo religioso, lo político y lo burocrático.

A Emile Durkheim, Maffesoli lo retoma planteando la idea de la pasión "de la D'Opulsión", de lo "delirante" en la vida social. Las justificaciones, las teorizaciones y las racionalizaciones vienen después. Lo primero es la pulsión que lleva a actuar, que anima a decir, que preside las diferentes asociaciones, que propicia las atracciones y repulsiones, que ordena las alianzas: en una palabra, todo eso "nologico" para Pareto. Para Durkheim (Michel Maffesoli, 1993), no hay representación colectiva que no sea delirante y este fenómeno que se comprueba en el caso de las creencias religiosas, puede considerarse como una "ley muy general". No puede expresarse mejor la importancia de lo sensible, del sentimiento irreprimible y desordenado en lo que se llama sociedad. Según Maffesoli, quizás ya no existe el totemismo que describe Durkheim, pero el interés de su análisis es el de destacar que se trata de una "ley muy general" que, con matices específicos, puede 
aplicarse a numerosas situaciones contemporáneas. Emerge la idea del mecanismo de "particípación" por medio de tal o cual tótem, que transforma al individuo en solidario del ambiente.

Así, diversas manifestaciones lúdicas e imaginarias son instructivas al respecto, incluso en el orden de lo político, pero más allá de ejemplos exacerbados, encontramos este mecanismo en la solidaridad básica que constituye la vida de nuestras comunidades. Basta con referirse al resurgimiento contemporáneo de los ideales políticos y religiosos, al apego a las ideas de territorio o país, al renacimiento de las familias extensas, a las reuniones musicales y a los festivales populares, a la importancia concedida a la ecología y a los circuitos de alimentos naturales, para convencerse de que es vano reducir la vida al sustrato económico o al fundamento fisiológico.

\section{II.- LA VIDA COMÚN Y CORRIENTE SE TEJE CON MIL HILOS ENTRECRUZADOS}

En El Conocimiento Ordinario (1993), Maffesoli muestra que ante nuestros ojos se está constituyendo un nuevo arte de pensar. Un arte que critica la engañosa oscilación entre dos polos: el de la razón y el de la imaginación como dos posibilidades aisladas en el conocimiento sociológico. Es por ello que reivindica la exploración de una sociología del interior, en la cual no exista abstracción del pensador y su mundo, sino la consideración de una realidad orgánica como fundamento de una sociología comprehensiva que sólo adquiera sentido en la vida cotidiana. Plantea entonces la urgencia de "que el discurso sobre lo social escuche el discurso de lo social, aunque su incoherencia pueda molestar a las inteligencias rigurosas formadas en el racionalismo de las Luces."(1993:52)

Del lado de la razón: la construcción, la crítica, el mecanismo. Del lado de la imaginación: la naturaleza, el sentimiento, lo orgánico. Cada una de estas actividades tiene sus propias reglas y su propia eficacia, que las lleva a elegir los objetos de su interés. Es por ello que deben ser complementarias. Para Maffesoli, la separación engañosa que produce la dicotomización entre razón e imaginación ha propiciado la división de los órdenes epistemológicos: por un lado la legitimación de un orden establecido y por otro, perspectivas críticas y utópicas. Es de esta dualidad que se deriva la existencia de una sociología positivista, -según la cual cada cosa es un síntoma de otra cosa-, y por otro lado, una sociología comprehensiva que describe lo vivido por lo que es y que se fundamenta en la noción orgánica de formismo sociológico.

La sociología positivista recurre a la necesidad de procedimientos y fundamentos de las ciencias naturales, anclados en el ideal que rige la realidad social desde finales del siglo XIX, cuando se cristaliza el desplazamiento de lo religioso, lo fantasmático y lo imaginario hacia la razón. Así, por ejemplo, el positivismo ha olvidado y descartado todo lo que le debe a la experiencia como actividad fundamental en la comprensión del individuo a través de la sensación y la experimentación colectivas. En este camino histórico de la era moderna nada parece escapar de la influencia del positivismo. Las ciencias humanas se fascinaron por las ciencias "duras" y sus procedimientos se desmarcaron del pensamiento filosófico y la especulación metafísica, para anclarse finalmente en un paradigma económico y normativo, el homo-economicus. Pero aún más importante, las verdades locales pretenden transformarse en verdades universales. Así, el saber absoluto se constituye en la premisa fundamental de las ciencias positivistas. 
En los postulados de Maffesoli encontramos una fuerte crítica a la reducción del conocimiento en la ciencia, ya que la pretensión hegemónica del saber absoluto que proclama el positivismo no sirve para captar toda la actividad del mundo social, ni tiene espacio para la pasión, lo ilógico, lo imaginario de la vida cotidiana que también estructuran la actividad humana y el hecho sociológico. Este ideal positivista es para Maffesoli precursor del totalitarismo, ya que todo lo que escapa de su influencia está en el error y por tanto no debe existir. Por ello, a su parecer, el error cientista está en que al desear construir un objeto puro, el positivismo olvida la ambivalencia del objeto social.

Sus críticas también aportan un fundamento político al impacto del positivismo en el ámbito académico al señalar que el imperialismo del positivismo está tanto más arraigado cuanto que nada parece escapar de su influencia, y a la vez nos recuerda la estrecha conexión entre el control social y la sumisión a la voluntad del saber que señala Foucault. El saber puede constituirse en una forma de poder, con lo cual la hegemonía del saber absoluto establecido en el pensamiento positivista se hace subsidiaria de pensamientos dominantes e instituyentes. En la ciencia y la institución académica se expresa esta hegemonía a través de una producción teórica que pone a funcionar la escritura universalista. Es así como existe una necesidad metodológica de emplear un encuadre para estructurar los fenómenos sociales y una preocupación intelectual de hablar a través de referencias a un autor o a un lugar. Para Maffesoli, la apariencia científica se apoya en el excesivo desarrollo del método cuantitativo y en el predominio del modelo normativo.

Esta opción cientificista refuta el proyecto de una sociología abierta que integre los saberes en un conocimiento plural; lo cual exige una escritura intuitiva, enfocada en la investigación estilística. Se trata menos de elaborar un contenido que de proponer una perspectiva determinada, sin pretender que el problema tenga una solución única, verdadera y definitiva. Sin embargo, esta opción comprehensiva de la investigación ha sido calificada de ensayismo y de carecer de rigor científico por las tendencias más duras de la vida académica institucionalizada. Es por ello que Maffesoli insiste en que la sensibilidad relativista se sitúe fuera de los cuadros epistemológicos clásicos.

Cuando el autor enfatiza que no hay una realidad única, sino maneras diferentes de concebirla (acorde a la pretensión de relativismo sociológico que enmarca sus postulados), no trata de invalidar los grandes sistemas explicativos que han dominado la tendencia positivista, sino de demostrar que son el resultado y la explicación de determinados períodos históricos. Las instrumentaciones psicosociológicas clásicas ya no bastan para describir una constelación social diversa y compleja en la cual la imagen y el símbolo ocupan un lugar preferencial. Por ello considera que se inicia una empresa libertaria que no pretende invalidar otros enfoques, sino evitar la contaminación a las posibilidades de su enfoque plural a través de la disipación de lo conceptual que da paso a la idea. Reivindica así un nomadismo o vagabundeo intelectual que permita superar el conformismo de los ámbitos intelectuales.

Al monismo positivista se opone el pluralismo que descansa en la idea del relativismo que Maffesoli reivindica. "El rechazo de la discriminación en cuanto al objeto y el rechazo del dualismo en cuanto al método suponen una organicidad social y natural." (1993:16). En tal sentido, propone que la búsqueda de lo social se produzca en un movimiento de vaivén, atento a lo instituyente y a lo clandestino y que se considere la existencia de diversos tipos de conocimiento, ya que el mundo social siempre se aleja cuando se cree haberlo captado y por ello es vano intentar alcanzar sus contradicciones y múltiples actividades. 
Su planteamiento se sintetiza en la idea de lo Plural y diverso en contraste con lo Uno. Lo que constituye la estructuración individual o colectiva no es el principio de identidad, sino la contradicción o alteridad que no pueden cuantificarse sino rescatarse en su esencia. De allí su propuesta de asumir la experiencia del relativismo para vincularse al mundo social de lo cotidiano. El relativismo "reconoce que la contradicción es constitutiva del ser y por tanto es insuperable" (1993:40); así, todo lo que el positivismo deseó borrar, retorna para significar que no hay un saber absoluto. Asume el relativismo como la empresa que permite captar mejor la riqueza del conocimiento social. Este conocimiento no puede reducirse a una verdad porque estamos en presencia de verdades manifiestas, múltiples, que se ocultan ante los tratamientos demasiado simplificadores del positivismo. En tal sentido, lo que importa no es la articulación de una verdad tendenciosa, sino de verdades locales y finitas y de carácter inacabado.

Retomando a Emile Durkheim, Maffesoli señala que si en la actividad social hay cierta lógica, ésta difiere de la que procede de nuestro razonamiento deductivo y tal vez obedece a otras leyes porque cada situación social es polisémica, plural, colectiva, polifónica. Clama porque se pongan entre paréntesis las creencias y que se invalide el saber absoluto y positivo, permitiendo tomar en cuenta los afectos, las pasiones y los aspectos poco serios de nuestra vida social. Sin embargo, destaca que esta estética no debe oponerse a la intelectualidad, sino que debe tratarse como saber complementario.

Pero, ¿es posible el equilibrio entre lo lógico y lo no-lógico del que está impregnada la situación social? Para abordar esta cuestión, Maffesoli retoma la noción de formismo siguiendo los planteamientos de George Simmel. A través de esta noción intenta describir la actividad social desde lo estético, lo aparente y lo imaginario, conociendo los contornos de las situaciones y sus representaciones en la vida cotidiana. En el formismo, Maffesoli asume una visión orgánica, holista y vitalista de la actividad social al considerar una fusión entre el actor y la realidad social a través de la idea del ser-conjunto que puede observarse empíricamente. Las formas, -por estar constituidas fundamentalmente de imágenes-, aprovechan la menor ocasión para manifestarse. Es por ello que las formas permiten una comprensión cualitativa de la vida cotidiana, como expresiones que ponen de manifiesto la polisemia de los sonidos, situaciones y gestos de la trama social.

Para Maffesoli, si bien el dato social es incoherente, lábil y polisémico, esto no significa que no se puedan observar sus formas estructurantes. Acorde con su concepción relativista del conocimiento, asume que las formas deben ser aceptadas como incompletas y en su aspecto parcial y efímero. De acuerdo a ello, las formas no expresan imperativos categóricos, sino que se conforman con expresar su tiempo; así lo formista constituye una condición de posibilidad, es decir, un punto de vista que se ancla en un tiempo. Es por esto que Maffesoli diferencia entre el formalismo conceptual, -que somete a la razón todo lo que observa-, y el formismo que se conforma en levantar grandes configuraciones que engloban los valores plurales y antagónicos de la vida cotidiana.

Considerar el esteticismo que hay en el mundo cotidiano, -expresado en ademanes, palabras, teatralidad-, equivale a una reflexión formista de esa sociedad. Representaciones de lo cotidiano como el poder, la fuerza, la orgía, la violencia, lo trágico pueden comprenderse como modulaciones de la forma, en tanto que no existen, son irreales, pero plasman en imágenes todos los significantes que constituyen nuestra sociedad. A través de las formas es posible reencontrar la coherencia detrás de lo aparente, sin recurrir a artificios y desnaturalizar el proceso; es por ello que el conocimiento formista deja ser al objeto que analiza. 
La idea de formismo insiste en el espectáculo, la imagen, lo sensible, realidades que el saber occidental ha descuidado y que expresan una estética social. En otras palabras, y de acuerdo con Gilbert Durand, lo trágico, la teatralización, el ritual, lo imaginario, son considerados categorías sociales, porque la existencia social sólo existe cuando se deja ver y cuando toma forma. Por ello lo que guía el proceso de conocer no es solo lo que un objeto es, sino la manera en que se deja ver, con lo cual la investigación social debe destacar el valor de los colores, la arquitectura, el ambiente intenso y trivial de la vida cotidiana. Así la forma permitirá captar tanto la imagen como su imposición en lo social.

Todos los aspectos de la vida social necesitan un simbolismo. Pero estas referencias no-lógicas son consideradas como remanentes retrógrados por las tendencias cientificistas de la vida académica. Maffesoli sostiene que la imposibilidad de suprimirlas es un dato fundamental en el conocimiento de la socialidad e implican un efecto de retorno continuo a los valores arcaicos. Los mitos fundacionales, por ejemplo, contienen una riqueza metafórica, simbólica e imaginaria de la cual es importante conocer todo su valor representativo para comprender el mundo social que está expresado en ellos.

La comprensión del pluralismo de lo social también requiere una actitud de empatía en el investigador para comprender toda la correspondencia entre la naturaleza y la cultura, la armonía conflictiva, la solidaridad y sus tensiones, "en una palabra, todo lo que puede llamarse socialidad volverá a ser perceptible desde una escala mas amplia en el discurso sociológico" (1993:52). Una actitud que también se desmarca de la tendencia aparentemente neutral y descontaminada que predomina en la investigación social dominante. En esta actitud empática, el sujeto se constituye en Uno con su mundo social disolviendo la falsa dualidad sujeto-objeto que desnaturaliza la esencia de la vida cotidiana y, a la vez, puede aproximarse a la realidad múltiple, compleja, polifónica e imaginaria de la socialidad.

\section{III.- DE LA ORGÍA}

Realzando la importancia de la emoción vivida en común y del sentimiento compartido, Michel Maffesoli propone el paradigma tribal como diagnóstico nuclear de las sociedades postmodernas. Un ethos común que adopta una expresión propiamente pasional y emocional, a lo que Maffesoli denomina como paradigma estético de cultura.

La sociedad postmoderna supera la noción de identidad del sujeto consolidado por la modernidad para perseguir formas de socialidad que provocan la disolución de la identidad en un sentimiento vivencial de comunidad, de estar juntos. Al respecto, Enrique Carretero (2003a) señala que llegamos a la exaltación de un narcisismo colectivo enraizado en una sociedad desindividualizante que favorece un sentimiento de pasión compartida. La pulsión de estar con el otro, la atracción social, encuentra su motivación en la empatía de participar junto al otro en un conjunto más vasto, contaminado por ideas, emociones e imágenes comunes (Maffesoli, 2003).

Maffesoli ofrece una clara explicación de lo que define a la modernidad, es decir un sujeto emancipado, individual y racional, orientado a una actividad productiva, también racional y lineal. En su texto De la orgía. Una aproximación sociológica (1996) el autor explica la necesidad de superar dichas características limitantes para volver a una posición más libremente centrada sobre los placeres improductivos y el sentimiento colectivo. 
Se podría decir que aquello que mejor caracteriza la posmodernidad y que va tomando cuerpo ante nuestros ojos es el vínculo establecido entre la ética y la estética. Este es un nuevo vínculo social, un ethos surgido de la emoción vivida en común, del sentimiento colectivo, stricto sensu, etimológicamente, esto es la orgía. Maffesoli señala que la orgía no ha de entenderse como frivolidad, vanguardia o bohemia artística, por el contrario, hay que ver en el hedonismo uno de los factores esenciales de la vida social que fomenta la pertenencia grupal y establece el orden social.

Orgía y hedonismo pueden parecer de un contraste insuperable frente al binomio ética y orden social, pero Maffesoli nos ofrece su clave de lectura: la moral dicta una serie de comportamientos, aquello hacia lo que el individuo y una sociedad deben tender, y la ética le remite al equilibrio y la revitalización recíproca de los diferente valores que constituyen el conjunto. La ética es ante todo un deseo de vivir global e irreprimible y traduce la responsabilidad que el grupo tiene de conservarse en cuanto tal. Además recuerda que con mucha frecuencia olvidamos que la anomia es el motor de toda sociedad y que lo orgiástico es una de estas aberraciones, si no la más significativa y completa.

"El acto de la extralimitación moral refuerza el vínculo ético, pues, al permitir expresar lo imaginario, lo lúdico y las fantasías, la manifestación y la representación del desorden recupera todo lo que configura la validez del vivir en común. Al contrario de la moral económica, que funciona siempre con la vista puesta en el mañana (religioso y profano) y que en consecuencia administra con mesura sus haberes materiales y afectivos, el goce del presente se agota en el mismo acto." (Maffesoli, 1996: 25)

Hay en la exposición de Maffesoli una absoluta y constante preeminencia del colectivo sobre el individuo y su correlato racional que es lo social, que provoca en el individuo el dejar de ser el dueño de sí. El yo es otro afirma Arthur Rimbaud, y sobre todo el yo se establece a partir del otro. El individuo se siente arrastrado por la excitación de la masa, como si ésta fuera una fuerza exterior, insensible a su ser y a su voluntad individual.

"El poner durante mucho tiempo el acento en el individuo, y después en el Individuo Social, ha hecho olvidar lo que, precisamente, es primordial para el hombre: el vivir en común. Mas allá del lo social, donde se expresa la solidaridad mecánica, encontramos la socialidad, que remite a la solidaridad orgánica, donde la relación con el cosmos y la relación con el otro se entretejen sin cesar." (Maffesoli.ob.cit:15)

Maffesoli afirma que el acuerdo societal se basa en una simpática convivencia con el universo, con la naturaleza y el entorno. En este conjunto cósmico, lo místico y dionisiaco toman una posición fuerte y proponen las variadas fusiones grupales como resurgimiento de prácticas dionisíacas, de forma directa o manifiesta, que expresan un deseo irreprimible de vivir, que la domesticación de las costumbres o el moralismo ya no saben canalizar. El desorden dionisíaco presenta la reversibilidad de las manifestaciones y la interrelación profunda que se establece entre los seres.

La vida improductiva y el goce del presente se vuelven los valores globales e ineludibles de una sociedad orgiástica. La alegría del "carpe diem" desafía el sistema económico y político que inútilmente intenta gestionar lo que necesariamente le escapa de entre las manos: el juego de la pasión y la estética de la vida, en contrapunto al utilitarismo. Hay un regreso a tiempos antiguos, 
donde lo lúdico presentaba el deseo de vivir y perdurar de la sociabilidad, con una concentración hacia el cuerpo y sus necesidades físicas: el cuerpo que pide lo inútil. La vida es arte de seducción, es agitación y promiscuidad, que no puede seguir una lógica y un tiempo lineal, sino que busca una dinámica cíclica y opuesta, de la abstención al exceso, del presente al instante.

"Así pues, frente a un tiempo histórico dominado por la producción y la parusía, existe un tiempo poético y erótico, un tiempo del ardor de los cuerpos; un segundo tiempo, escondido, al rededor del cual se organiza la permanencia de la socialidad. En torno a este tiempo se articula la perduración de un profundo politeísmo que se enfrenta al proceso reduccionista y totalitario del monoteísmo religioso y político." (Maffesoli.ob.cit:49)

Hablando de lo orgiástico como factor de sociabilidad, Maffesoli cita a la par de la sensualidad al sexo, como elemento de la aventura existencial, presente en toda estructura social, y, como él dice, en humildes situaciones diarias como comer y beber. Baco, el federador, incita a liberarse de las angustias de la realidad y dedicarse frívolamente a lo bueno y, como consecuencia natural y buscada, a la agregación social. En el consumo orgiástico se expande el cuerpo, pero no se pierde la practicidad de los valores, que se vuelven puramente sociales.

"Mientras que el orden, sea cual sea, funciona siempre según el espíritu de Uno, según una monovalencia, la irrupción del desorden remite al fundamento, a lo polidimensional, a la pluralidad de los valores. Las pasiones desencadenadas son difícilmente controlables porque reúnen todos los elementos que, la mayor parte del tiempo, están ocultos en la estructuración social; y, en este sentido, son subversivas." (Maffesoli.ob.cit.:122-123)

Para tener un acceso a dicho desorden productivo, las culturas se hacen rituales propios, codificados por reglas, que fácilmente permanecen poco visibles o invisibles. Así, carnavales, fiestas del vino, juergas estudiantiles, reuniones religiosas, esconden su utilidad, la función socialmente asignada en la obscenidad y el desenfreno. Los rituales y las costumbres se adaptan, aunque nos parece que sean éstos los que despiertan las necesidades y potencialidades del propio cuerpo y lo vuelven cuerpo social. El desorden permite desahogar la violencia acumulada, y restablece la virtud del pueblo.

A través de las palabras de Durkheim, Maffesoli expresa cómo una comunidad reaviva el sentimiento de sí misma:

"A una regla exterior y esclerotizada, lo orgiástico opone los rituales, sus reglas, a modo de contrafuegos; en este sentido, lo lúdico es serio y un elemento de socialización." (Maffesoli.ob.cit.:127)

La orgía se vuelve en nuestra sociedad un poco el fulcro de la sociabilidad, que en su caos esconde las reglas informales al orden social y a la ética popular. En contraposición a la linealidad racional se presentan rituales con contenidos y funciones diferentes. La regularización del orden social, la intensificación del sentimiento grupal o la excitación colectiva, la iniciación de jóvenes o extraños a ciertos eventos cultural-sociales: 
"A propósito de la excitación colectiva Proust ofrece una interesante reacción a la intensidad colectiva, llamándola de vicio colectivo. El vicio se podrá fortalecer al rememorar la excitación colectiva. La expresión del vicio colectivo en la excitación de la fiesta no disipa, no anula como se cree, sino que hace de ella una epifanía, una exaltación que será punto de referencia cuando llegue la monotonía cotidiana; en este sentido reafirma la oposición a las imposiciones sociales." (Maffesoli.ob.cit.: 142-143)

Por cuanto a la iniciación sobre todo de jóvenes a detalles sociales, como por ejemplo a la vida sexual, la orgía y el ritual permiten guiar la evolución según las líneas preestablecidas por la cultura. Así, la sociedad se queda con el control del tiempo y de la angustia que provoca la primera experiencia y hace de ella una referencia necesaria.

Los rituales y las orgías están presentes en todas las culturas, Maffesoli tiende a citar más bien culturas orientales e indígenas, que en comparación con las nuestras, nunca han dejado de lado los ideales místicos y dionisíacos y pueden servir como ejemplos a seguir. Los rituales además de perseguir objetivos comunes, se presentan con elementos similares, entre ellos el desorden y el caos, lo oscuro, la noche, lo violento. Todas ellos aluden a una cierta teatralidad y a una intangibilidad desde afuera, así como a la incontrolabilidad.

La orgía representa, en la cultura societal, el correspondiente del caos en la teoría de la complejidad: la aparente confusión aleatoria está dirigida por secuencias y lógicas dinámicas y es particularmente sensible al entorno y sus cambios. Eso hace de lo orgiástico desde Maffesoli, un fuerte promotor de la cultura gracias a la continuidad y la estabilidad entre las características comunitarias.

\section{IV.- LA NEO-TRIBALIDAD}

Frente a la saturación de la época moderna, -que exaltaba los grandes valores de fe en el futuro, el progreso y la razón-, Maffesoli propone la gestación actual de una nueva composición del cuerpo social. La postmodernidad presenta una nueva organización social que da lugar a las tribus y la masa y ya no al individuo y la sociedad.

Su propuesta de la saturación de los grandes valores que compusieron la Modernidad y de los cambios que están surgiendo dentro de la vida social actual se aprecia a través de las siguientes premisas:

- Frente al planteamiento moderno de la individualización, propone que en la posmodernidad los individuos buscan "estar juntos", buscan ser parte de una comunidad.

- Frente a la razón, que propone a los individuos unirse por un proyecto común, razonable y lógico para todos, expresa que en la posmodernidad se da un "estar juntos" que viene matizado por una razón sensible, erótica, es decir, un "estar juntos" por un interés sentimental, no por un interés común en un proyecto político o religioso. Se trata, entonces, de un "estar juntos" por la empatía, por el sentimiento, por la emoción, por el deseo, los sueños, la imaginación. 
- Frente a la fe en el futuro de la modernidad, aparece en la posmodernidad una atención especial en el presente, en lo que se vive en el aquí y ahora.

Es importante rescatar que para Maffesoli se trata de la saturación de una época y no del fin de una época. Esta diferencia se puede comprender en el siguiente comentario tomado de una entrevista publicada en el diario argentino La Nación:

\begin{abstract}
"En química, hay saturación cuando las moléculas que componen un cuerpo se separan. Sin embargo, al mismo tiempo, con esas moléculas se produce la composición de otro cuerpo. En nuestro caso se trata de la saturación de los grandes valores que compusieron el modernismo- fe en el futuro, en el progreso, predominio de la razón- de esos valores que marcaron los siglos XVII, XVIII, XIX, hasta los años 50 o 60 del XX. Ese fue un gran ciclo, bien elaborado, que dio como resultado la sociedad moderna....Ahora hay saturación. Simplemente, porque en un momento determinado se produce una fatiga, un hartazgo, el desgaste de un modelo, de un paradigma. $\mathrm{Y}$ en el momento de esa fatiga observamos una recomposición." (http://www.lanacion.com.ar, 2005)
\end{abstract}

Para continuar explicando cómo se produce esta recomposición de la organización social Maffesoli retoma otro concepto, el de cenestesia, para pensar como se puede dar una transición entre la modernidad y la posmodernidad:

"La palabra fue utilizada por los médicos en el siglo XVII cuando hablaban de "cenestesia corporal". Esto denomina el proceso por el cual los diferentes órganos se ajustan unos en función de otros, y el fluido en función de lo sólido. Después fue la psicología la que utilizó el concepto para referirse al niño que aprende a caminar: se cae, se golpea, se vuelve a caer... hasta que por fin adquiere la cenestesia (la percepción correcta de su entorno y de sí mismo) y comienza a caminar. En el caso del cuerpo social, podríamos imaginar que habrá, después de numerosos aprendizajes, de errores y caídas, cenestesia del cuerpo social. Es decir que las diversas tribus sabrán ajustarse en función de las necesidades del resto, hasta alcanzar el equilibrio. Por el momento, creo que estamos en el período de aprendizaje." (Ibidem)

Es precisamente ubicándose en un terreno nuevo de "aprendizaje", el de la vida cotidiana, desde donde Maffesoli intenta conocer algo de estos cambios. Señala que la posmodernidad no se puede explicar utilizando las categorías de la modernidad, por esta razón, considera que es necesario inventar nuevos conceptos que den lugar a un nuevo paradigma.

Según Maffesoli lo social, la noción de sociedad, se ha saturado y lo que nos queda es la socialidad. Expresa que en la posmodernidad se está estableciendo una "forma social" que no se sabe si es germen de otra sociedad, pero que da cuenta de un rompimiento con la acción individual y la estructura impuesta. De esta manera, propone que hay un pasaje de la polaridad individuo/sociedad a la polaridad tribus/masas (entidades no orientadas, no finalizadas). Se trata en la posmodernidad del 
advenimiento de un nuevo grupo: las tribus. De una nueva "forma social": la masa. De un nuevo hombre: el nómade.

Precisamente este pasaje a la posmodernidad provocado por la saturación llevó a un estallido de las diferencias, provocando la proliferación de muchas microcomunidades, heterogéneas entre sí, que se comenzaron a unir por una afinidad compartida. De esta manera, se puede observar actualmente la existencia de diferentes grupos que se constituyen a través de sentimientos y experiencias comunes. A estos grupos les llama tribus y afirma que puede tratarse de tribus musicales (tecno, góticas, metal), artísticas, deportivas, culturales, religiosas, sexuales (bisexuales, homosexuales, heterosexuales).

Considera que las tribus son nudos que forman parte de una red, una red que las conecta entre sí. Esta red es la masa a la que define como una entidad autosuficiente, es decir, sin fines. Esta característica de ser la masa una entidad sin fines es, precisamente, la que le permite contraponerla con la noción de sociedad, en la cual se entiende que se tenían delimitados fines comunes. La masa en la época posmoderna no ofrece un marco delimitado para las acciones sociales, simplemente funciona como sistema de redes, que permite articulaciones. Es importante recalcar, entonces, que hay un vaivén necesario entre las tribus y la masa y que, precisamente, la masa se difracta constantemente en tribus. Además define un nuevo hombre, el nómade, que va de una tribu a otra, que no tiene una única identidad ideológica, sexual, profesional o de clase, que no se deja encerrar dentro de roles que antes eran definitivos, en instituciones como el matrimonio. Así, lo fundamental de rescatar es que el nómade puede pertenecer simultáneamente a diferentes tribus.

De esta manera, Maffesoli propone pasar de la sociedad (de lo social) a la socialidad. Expresa que la sociedad esta hecha de individuos y la sociabilidad de personas. Que el individuo tiene una identidad y la persona se identifica con un rol, es decir representa un papel, se pone una mascara. Así, en la posmodernidad se pone el acento en las identificaciones de las personas y ya no en la identidad del individuo. El individuo se encierra en su identidad (se agota en su función), la persona se identifica con sus simultáneas o sucesivas máscaras sin agotarse en ninguna de ellas.

De allí que en la posmodernidad se esté dando un movimiento hacia la búsqueda de pertenencia a una comunidad y no hacia la individualidad. Esta nueva forma de socialidad, retomando las palabras de Maffesoli, "no reposa en una distinción con respecto al otro, ni tampoco sobre un contrato racional que me ligue al otro, sino sobre una empatía que me hace partícipe junto al otro de un conjunto más vasto, contaminado por doquier de ideas colectivas, emociones comunes e imágenes de todos los órdenes." (2003:153). Así, se puede observar como a través de la constitución de esta nueva organización social se abren las puertas a lo imaginario en la posmodernidad, y en palabras de Maffesoli, se está dando un reencantamiento del mundo.

Se habla de reencantamiento del mundo porque se construyen espacios para el florecimiento del mito y lo imaginario, algo que la modernidad excluyó. Se trata del retorno de elementos como los sueños, lo inconsciente, las fantasías, a los que Maffesoli llama alógicos, precisamente porque están fuera de la lógica de la razón. Desde estos elementos es desde donde se organizan las tribus posmodernas: desde la emoción y no desde la razón. Así, se puede fundamentar que la constitución de las tribus tiene como pilar fundamental lo imaginario, entendiéndolo como contraparte de lo racional establecido. Lo imaginario aparece vinculado a la sensibilidad, es decir, a formas de coparticipación comunitaria movidas por una actitud sentimental. De esta manera, las tribus se constituyen con el fin de funcionar como receptáculos de acogida, no para realizar un proyecto. 
Se trata de formas de relación social de tipo empático en donde se da un sentimiento de comunidad ligado a lo presente. No interesa el futuro, sino vivir en el aquí y ahora. Se trata de la exaltación de un narcisismo colectivo, de una socialidad desindividualizante, amparado en un sentimiento de pasión compartido. Lo imaginario constituye el mundo posmoderno al que Maffesoli llama un "mundo imaginal", precisamente, porque el vínculo social se refuerza por la "cosa mental" y no por lo racional establecido. En la posmodernidad resurge la imagen. La imagen es algo del orden de lo relativo, no aspira a lo absoluto, a la exactitud, a la comunión con todos los miembros de la sociedad. La imagen pone en relación, no le interesa la certeza, el dogma, el "buen" razonamiento.

Este relativismo que vuelve a tener fuerza con la reaparición de lo imaginario en la escena de la vida social abre así el espacio a las cosas sensibles, emocionales, frívolas, presentes en lo cotidiano. Permite que se cuenten historias, no La Historia. En este sentido la imagen constata un impulso vital, una estética emocional en todos sus afectos, sean refinados, de mal gusto, desenfrenados, kitschs, explosivos o conformistas. A este dejar hacer o dejar ser de la posmodernidad, diferente de la razón moderna que propone hacer lo que ya está decidido, Maffesoli le llama la función icónica de lo imaginario. Según Maffesoli, la imagen, el fenómeno, la apariencia, el sueño, los fantasmas son tomados en serio en la posmodernidad. Este es un resurgimiento de lo imaginario que le otorga a la imagen dos funciones vitales: primero, la de poner en relación, relativizar; segundo, la de conducir al vínculo.

Con relación a la primera función, como ya se ha mencionado, el mundo imaginal se puede concebir como una matriz donde todos estos elementos "mundanos" entran en interacción y en donde pueden corresponderse de diferentes maneras. Así, en la posmodernidad se estaría dando paso a esta diversidad de formas de representar y mirar el mundo, a esta posibilidad de comulgar con diferentes ideas. Por esta razón, se podría decir que se trata de un reencantamiento del mundo a través de una serie de "fés sin dogmas". Es decir, habría múltiples éticas con valores propios que funcionarían en cada comunidad tribal de distinta manera. Así, no se estaría dando un compartir de valores universales, sino un compartir valores emocionales particulares de cada tribu. Con relación a la segunda función de la imagen, la de conducir al vínculo, es importante entonces seguir en la línea de lo anterior y decir que se puede concebir a las tribus como conjuntos con "fe sin dogma", es decir, comunidades en donde sus integrantes comulgan y se unen por una idea, una imagen, un fenómeno, una pasión.

Las tribus (sexuales, deporte, conciertos musicales, concentraciones patrióticas, reclamos consumistas) constituyen su modo particular de vínculo a través de lo imaginario. En palabras de Maffesoli, "el vínculo se configura alrededor de imágenes que compartimos con los demás, puede tratarse de una imagen real o de una imagen inmaterial, o incluso de una idea con la que comulgamos, cualquiera que sea." (2003: 152). Este acto de comunión con una idea o una imagen deja ver algo de esa religiosidad que se encuentra siempre presente en la vida social. Siguiendo a Durkheim expresa que la religión es ante todo esa pulsión que me une al otro. Es desde esta visión desde donde plantea que en la posmodernidad, frente a cierto debilitamiento en la fuerza de convicción de los relatos religiosos, hay un retorno de lo arcaico, de esta pulsión de estar con el otro, de la atracción social.

La función de lo imaginario con relación a las tribus es la de matriz. Esta función se presenta en forma de continente de acogida que proporciona una identidad social como un espacio que conforma una congregación comunitaria en torno a emblemas simbólicos. Es muy importante esta función de lo imaginario en las tribus porque en la medida en que genera un sentimiento de pertenencia y de 
reconocimiento a sus miembros. De esta manera, se puede considerar a lo imaginario como matriz desde donde se busca conservar la vida social. Matriz que alberga el mundo de las imágenes, sueños, fantasías, deseos, experiencias cotidianas y desde donde cada tribu puede elegir esos elementos de lo imaginario con los cuales busca sostenerse y conservarse.

La imagen (ya se dijo, puede ser material o inmaterial, una idea) se puede entender como ese elemento elegido por una comunidad que le sirve para unirse, para organizarse de forma particular. Imagen desde donde se adquiere un lugar, un nombre, en lo social. Es precisamente esta omnipotencia de la imagen en la posmodernidad lo que parece permitir que las personas interactúen en la vida social y que, a partir de esa interacción, construyan un imaginario común, un sentimiento compartido. De esta manera, lo imaginario remitiría a una inmaterialidad, a ese mundo imaginario que se vuelve materializable a través de la imagen. Es por medio de su materialidad, entendiéndola como la imagen adquiriendo una corporalidad espiritual, que el espíritu "imaginario" adquiere una forma material y concreta por medio de la congregación simbólica, de decir, por su facultad de movilizar y fusionar las diferentes sensibilidades.

\section{V.- DE LA BELLEZA COMO FIN}

En la contemplación hay un goce, un deleite, un instante de vértigo ante la complejidad y abundancia de mundo. La realidad seduce, porque nos trastoca, nos atraviesa. Abrimos los ojos y los poros y al tratar de diferenciar y nombrar, los objetos se aglutinan. No existe la pureza y la fe en un futuro mejor es necia. El mundo no será jamás mejor ni peor de lo que es ahora, de lo que siempre ha sido. ¿Y entonces? Si la modernidad controla y demanda acción, la resistencia no es la re-acción, sino la paradoja: contemplemos, gocemos.

Cambiemos la razón abstracta por una razón erótica, invita Maffesoli, y al usar este término asume que habrá desaprobaciones y malentendidos. Erótica en el sentido más amplio del término, repite constantemente el autor. Busquemos esta amplitud al estilo maffesoliano, a través de los mitos, y para ello inventemos un encuentro entre Elogio de la razón sensible y "El Banquete" de Platón. En este diálogo varios han sido invitados a comer en casa de Agatón, ya todos reunidos, Sócrates será el último en llegar. Decidirán beber con mesura y cada uno pronunciará un elogio a Eros, el dios del amor. ¿Quién es Eros, cuáles son sus cualidades? Por Diótima sabremos de su nacimiento: cuando nació Afrodita, la diosa de la belleza, los dioses realizaron un banquete, entre los invitados estaba Poros, dios de la abundancia, de los recursos, de lo exuberante. Después de comer y embriagado de néctar (aún no existía el vino) Poros entró en el jardín de Zeus y entorpecido, se durmió. Sabiendo que habría migajas, Penia, la diosa de la carencia y la pobreza, toda ella en harapos, vino también a la fiesta. Al ver a Poros tan brillante, e impulsada por su carencia de recursos, tramó hacerse un hijo de él, se acostó a su lado y concibió a Eros. Al ser engendrado en día del nacimiento de Afrodita, Eros será su fiel acompañante, por naturaleza amante de lo bello. Por el origen de su madre Eros es siempre pobre, duro, seco, descalzo y sin casa, pero por otra parte y de acuerdo a la naturaleza de su padre, está siempre al acecho de lo bello y de lo bueno, ávido de sabiduría y rico en recursos. (Platón,1981).

En "El Banquete" Eros representa la unión de lo superior con lo inferior, el brillo y majestuosidad de Poros con la opacidad y miseria de Penia. Al plantear una razón erótica Maffesoli sugiere la necesidad de un principio que reconcilie y contemple, como en la naturaleza de Eros, la realidad en 
su dualidad. Es por ello que contrapone dos términos, el de unidad y unicidad. La unidad nos habla de lo cerrado, estático, completo, mientras que la unicidad mantiene de manera contradictoria, la cohesión de todos los elementos fragmentados de la realidad social. Es a través de la forma que esta cohesión es posible, sólo así se cristaliza el deseo de unicidad que anima todas las cosas. Trascendiendo la fragmentación inherente a la vida cotidiana, hay una aspiración a la convergencia, que se manifiesta con claridad en la búsqueda estilística como exacta conjunción de la materialidad y el espíritu. Poros, Penia y Afrodita, abundancia, carencia y belleza.

El racionalismo es incapaz de captar el aspecto prolijo, lleno de imágenes y simbólico de la experiencia cotidiana. Ignora las coincidencias de opuestos, donde seres y fenómenos completamente antagónicos pueden unirse. En su búsqueda de esencia y constancia, asume la existencia de unidades indivisibles, inalterables, lineales y unívocas. Paradójico es el nacimiento de Eros de padres tan distantes, así también la propuesta de Maffesoli respecto a una razón-sensible, en la que pretende conjugar dos términos que históricamente han guardado un constante antagonismo.

El saber erótico de Maffesoli propone una aceptación del mundo como es y no como debiera ser, que reúna en si las sombras y carencias humanas tanto como las pasiones y las sensibilidades. Se sugiere un pensamiento de acompañamiento, una metanoia (que piensa al lado) por oposición a la paranoia (que piensa de una manera dominante). Abordando la cuestión de la experiencia vivida, el sentido común y lo sensible, se hace una crítica reiterada a los principios, ideales y métodos que han dirigido el quehacer intelectual a lo largo de la modernidad, acusándoles de áridos, fragmentarios e insuficientes para dar cuenta de la complejidad de la experiencia humana y particularmente de la sensibilidad emergente en la posmodernidad.

El concepto de razón erótica de Maffesoli obliga a un reconocimiento del deseo de aquel que busca conocer. Haciendo nuevamente referencia a "El Banquete", el que desea, desea aquello que no tiene, lo que no es él mismo, de lo que está falto. Hay una referencia a la alteridad, a lo extraño del otro y de lo otro y a la carencia de un sujeto que no se basta a sí mismo y que para ser requiere de la relación y el encuentro con esta alteridad. Contra la figura del científico experto y poseedor de saber, Maffesoli propone la de un contemplador menesteroso, deficitario, deseante de experiencia del mundo, en constante tensión entre separarse y fundirse, ante todo no autosuficiente. Alejándose de los ideales dominantes, es necesario un conocimiento que responda a la libido sciendi, "un saber erótico que ama el mundo que describe", nos dice el autor, una racionalidad amorosa, relacional, conjuntiva, auto conciente de su propia imperfección cognoscitiva.

El conocimiento moderno ha basado su construcción de saber en el establecimiento de categorías y conceptos. Conceptos que captan, que atrapan. Jugando con una proximidad de sonido Begriff, -en alemán concepto-, no deja de evocar el hecho de griffer (en francés arañar) arañar aquello a lo que se aplica. Este es el fundamento mismo del concepto, arañar, dejando su marca en aquello que constriñe al nombrar. Frente al concepto, Maffesoli sugiere a las ciencias sociales una mirada desde la forma como es entendida en la estilística. El estudio estilístico (concepto que toma de W. Saphiro en La Notion de style) constituye una búsqueda de correspondencias, que se explican a través de un principio organizador que determina a la vez el carácter de las partes y la disposición del conjunto. Los rasgos caracterizados de un estilo presentan una cualidad en común y a la par respetan las particularidades de cada una de las partes. Al contemplar un fragmento artístico el especialista es capaz de reconocer un estilo determinado. Lo mismo sucede con la vida social, donde es posible reconstruir una época específica a partir de un detalle, una manera de ser, un objeto, un modismo. Esta organicidad social es plural y a la vez constituye una sólida coherencia. 
Maffesoli hace referencia a dos pensadores como ejemplos de esta manera de construir conocimiento: George Simmel y Walter Benjamin. Ambos han diseñado una sólida arquitectura a través de micrologías, fragmentos y variaciones alrededor de un mismo tema. Abordando elementos específicos y haciendo referencia a su unicidad, han dado forma a las particularidades de su contexto. La definición de trabajo intelectual para Maffesoli es muy clara, consiste en "captar el efecto de composición que se halla en el origen mismo de un país, de un grupo, de un estilo artístico, de una sensibilidad política o religiosa, y entender que este efecto de composición es estructuralmente uno y múltiple a la vez." Maffesoli (1997:94).

Hay cierta similitud entre algunas características de la forma y la noción de ritmo en los griegos. Ritmo es aquello que se desarrolla a partir de un dibujo, de un esquema, no es algo desordenado, sino que surge a partir de una limitación que le permite ser un enlace entre lo estático y lo dinámico. Similar a la forma, el ritmo "es lo que impone unas ligaduras a los movimientos, es lo que contiene el flujo de las cosas." (Jaeger, W. en Maffesoli. Op.Cit:78). A la par se encuentra el sentido de esquema, también en los griegos, como aquello a partir de lo cual una estructura, sea cual sea, va a desarrollarse y esto vale para una escultura, una idea filosófica, una danza. Si queremos comprender la evolución y dinámica de algo, es necesaria la contemplación de su forma, de su estructura, de este punto nodal a partir del cual surge su estabilidad y dinamismo. La forma precisa un esfuerzo de reflexión ya que la contemplación en sí misma no revela ningún contenido preciso, sino que se contenta con describir un continente. El resultado es un "saber raro", que simultáneamente revela y esconde aquello que describe.

La metáfora jugará un papel fundamental en la medida en que se sitúa justo en la intersección entre lo sensible de la vida social y su integración en el acto de conocimiento. La metáfora es el logos revelado en imagen, significado vuelto forma. Nuestras sociedades están animadas por el juego de imágenes en un estilo que acentúa la estética, lo cotidiano y lo simbólico. Con el término formismo Maffesoli indica la preeminencia de la apariencia, evidenciando la forma como seno de todos los fenómenos estéticos que delimitan la cultura posmoderna. Mientras que la modernidad y su dialéctica pretendían ir más allá de lo contradictorio, dando un sentido y finalidad al mundo, el formismo reúne los contrarios y favorece un sentido que se consuma en el presente, en actos, que no se proyecta y que se experimenta en el juego de las apariencias y las imágenes. Hemos de distinguir entre forma y fórmula. La fórmula da soluciones, impone certidumbres, tiene respuestas. La forma, en cambio, se contenta con plantear problemas y ofrece "condiciones de posibilidad" para dar respuestas particulares, abiertas, siempre incompletas. Para referirse a la realidad, la forma caricaturiza, exagera los rasgos y así hace resaltar lo subterráneo.

El Renacimiento, el romanticismo alemán y la poesía baudelairiana son ejemplos de un vínculo indisoluble entre razón y sensibilidad representantes del gozo intelectual. En estos casos el arte de pensar es verdaderamente un arte e integra una dimensión estética que más tarde será aislada y reducida a las "bellas artes". A partir de aquí se le restringirá al campo de la distracción y como característico de lo no serio de la existencia, por oposición al sentido de lo útil, del poder, es decir, de una visión económica del mundo. Una concepción así "es fundamentalmente incapaz de comprender el aspecto creativo de la vida fuera de la dimensión del "hacer", de la acción, del activismo incluso." (Maffesoli, 1997. Op.Cit.:52).

En el mito bíblico cuando el hombre come los frutos del árbol del conocimiento es separado de una vida de puro deleite, afecto y comunión con la naturaleza. Siguiendo esta metáfora, el gozo y la contemplación ceden el lugar a la acción, "acción sobre sí, acción sobre el mundo" por medio de una 
ciencia. Esta concepción escindida y unilateral de la realidad humana amputa la dimensión imaginativa y olvida que "en la realidad misma la imagen, la intuición y el concepto están (...) fuertemente unidos" (Op.Cit.:55).

La representación ha sido la palabra clave de la modernidad, tanto en los cimientos de la organización política y el ideal democrático, como en los sistemas interpretativos que pretenden representar el mundo en su verdad esencial y universal. Al respecto Maffesoli propone la sustitución de la representación por la presentación, no como un mero cambio lingüístico, sino como un giro radical de las bases epistemológicas. La presentación se contenta con dejar ser lo que es y se esfuerza por resaltar la riqueza, el dinamismo y la vitalidad del mundo presente. Contra la pretensión de depuración, reducción y búsqueda de perfección de la representación, la presentación subraya que nunca podremos vaciar totalmente un fenómeno empíricamente vivido a través de una simple crítica racional. Esta aceptación o acomodación a un mundo tal como es y señalada por Maffesoli como característica de la posmodernidad, nos remite a una "contemplación del mundo" a partir de donde podemos insistir en el análisis de las formas y también en aquello que Gilbert Durand denomina el "papel cognitivo de la imagen", imagen que no busca la verdad unívoca, sino que se contenta con subrayar la paradoja y complejidad de cualquier cosa. Lo particular de esta actitud de espíritu es "no trascender lo que es manifiesto, no aspirar a un más allá, sino ajustarse a las apariencias, a las formas que son evidentes, y hacer resaltar la belleza intrínseca de las mismas." (Op.Cit.:25)

Para explicar la relación realidad-forma-estética, Maffesoli retoma a Simmel afirmando que la belleza es siempre la forma de elementos que por sí mismos son extraños a la belleza. De acuerdo con esta definición, una palabra, un color, o un trazo son en sí mismos neutros, es sólo en el momento en que una multiplicidad de ellos se yuxtaponen y toman una forma que surge la originalidad de su belleza. Es esta "aglomeración instauradora de forma" la que constituye la belleza y también la que da forma al tejido social. Hay un querer vivir estético que sustenta la tesis de Maffesoli, donde la contemplación del mundo se defiende ya en sí misma como una forma de creación.

Congruentes con el espíritu del autor, contemplemos las formas de la pintura en el período Barroco, al que Maffesoli hace referencia en búsqueda de metáforas que den forma al espíritu de la razón sensible. Según la Real Academia Española, el término portugués barroco significa perla irregular con altibajos, de ahí que barroco es lo extraño, confuso e irregular. En la historia del arte, este período se caracteriza por plasmar el movimiento en oposición a la estabilidad, dando prioridad al uso de líneas curvas, antes que líneas rectas. A diferencia del arte clásico en donde reinaba la razón, el Barroco extrema la sensibilidad al límite, rechaza el uso de una luz clara y limpia e introduce el juego sutil entre lo claro y lo oscuro permitiendo la desaparición de los contornos.

El Barroco resalta elementos que la modernidad ha ignorado en su categorización de la vida cotidiana y que resurgen en la posmodernidad. Enfatiza la impresión de transformación y dinámica continua, nos recuerda que en la sociedad contemporánea "nada está hecho con líneas duras o marcadas, todo funciona sobre la ambigüedad (...) Nos encontramos frente a una fantástica ley del embotamiento que actúa más por difuminación que por seguridad del contorno o del propósito". (Maffesoli, Op.Cit.:49). La posmodernidad tiende a un sincretismo de perfiles poco limitados que demandan la interpretación de diversos papeles insertados en juegos de apariencias y claroscuros. Así, la mirada barroca se dirige a lo sublime de esta perla que es la realidad, no pura y perfecta, sino como la pintura barroca, de composición asimétrica, en desequilibrio, con figuras cortadas que 
parecen continuar fuera de los límites del lienzo, entre ondulaciones, asumiendo lo extraño, lo desconocido y lo bárbaro de la dimensión humana.

Sí, Maffesoli-relativista, o lo que el mismo ha llamado un "relativismo hedonista" donde lo característico es "desconfiar de las diversas generalizaciones o sistematizaciones más o menos apresuradas, y encariñarse por lo que la existencia ofrece de concreto, de próximo y de particular." Retomando lo que Dilthey denomina "una afectuosa profundización de la particularidad", Maffesoli afirma que en efecto, "hay algo de sensible, sensual, sensualista, en una relación con el mundo y con el otro vivida al día y que busca su fondo en la experiencia". Criticando todo aquel conocimiento activista que pretende señalar y construir un mundo como "debiera ser", este autor vuelve la atención al presente, a la aceptación y vivencia del mundo "como es". Maffesoli no sugiere estrategias de acción política, sino maneras de gozar, contemplar y deleitarse. No sólo no se defiende de ser llamado místico, hedonista y carente de rigor científico, sino que él mismo se nombra así, afirmando con orgullo y entusiasmo que estas son las características de la posmodernidad y por tanto las que debe tener aquel que pretenda abordarla. Desdeña la rigidez académica y a aquellos que osan no aceptarlo, los increpa con su peor insulto: "iModernos!".

\section{VI.- OH TIEMPO, SUSPENDE TU VUELO}

En su texto El instante eterno. El retorno de lo trágico en las sociedades posmodernas (2001) Maffesoli afirma que se asiste hoy al retorno de una serie de valores arcaicos al primer plano de la vida social, en los mundos occidentales de la llamada posmodernidad. Junto al debilitamiento de las certezas en el pensamiento, emergen fenómenos juveniles tales como nuevos tribalismos y nomadismos que implican además, en sentido estricto, una actitud trágica ante la vida que se revela en diversos episodios de la experiencia cotidiana, numerosas prácticas sociales, que sin tal referente, parecen no tener ningún sentido.

A través de dicha sensibilidad trágica, el tiempo posmoderno se detiene, se inmoviliza o al menos se hace más lento en contraste al signo dramático de la modernidad que fue el desarrollo científico, tecnológico y económico acelerado. La vida social de hoy parece más bien una concatenación de instantes detenidos a partir de los cuales habrá que seguir el imperativo clave de la re-creación. Se trata de un cambio de paradigma desde una concepción egocentrada -que otorga primacía al individuo racional que vive en la sociedad contractual de la modernidad- a otra concepción locuscentrada -que pone en juego grupos o neotribus que generan espacios de convivencia específicos en la posmodernidad naciente-

Así, el individualismo moderno es dramático mientras la actividad tribal posmoderna es trágica, y en tal condición trágica, Maffesoli incluye los momentos de júbilo desbordado, la efervescencia por la vida. La noción de historia, como categoría central de los análisis de la modernidad, se relativiza. Se pasa de un tiempo lineal, singular y sustentado en la idea de proyecto, a otro tiempo cíclico, recursivo, presentista, que quiere deslindarse del utilitarismo burgués y que lleva el signo de la pluralidad. Se asiste pues a cierto retorno de valores, maneras de ser y de pensar, que desde la modernidad, habían sido ubicados en el ámbito de un presunto oscurantismo. Modos de vida menos racionales y más dionisiacos; menos sedentarios y más nómades que involucran de una u otra forma muchas prácticas contemporáneas. Se trata de un vitalismo que invita a la risa escandalosa de nuevos paganismos ante el envejecimiento de los mundos de la seriedad y de la programación disciplinada. 
Renace una vitalidad polisémica que no sigue los pasos de ese progresismo inocente y optimista de otros tiempos. Se vive una lógica de la conjunción más que de la disyunción. Emergen pues actitudes presentistas en las nuevas generaciones, orientadas a diversos hedonismos y mimetismos neotribales en un marco de permanente reversibilidad. Ante el ideal moderno de la autonomía, tiende a imponerse la práctica de la heteronomía y de la atracción apasionada. Ser joven se convierte además en un nuevo imperativo categórico que implica incluso maneras de vestirse, de hablar y también una manera de cuidar el propio cuerpo. En efecto, Maffesoli alude a una serie de fenómenos juveniles actuales que van desde concebir a los enormes centros comerciales no como el simple lugar funcional de venta sino como ocasiones de comunión, hasta las fiestas rave o tecno, así como los love parades, pasando por otros tales como la importancia de la moda, la astrología, las telenovelas ("eternidades de bolsillo") o el consumo de videoclips, juegos informáticos, utilización del ciberespacio, auge de la ciencia ficción en el cine o la pintura, la asunción de amores sucesivos y efímeros, cierto culto a lo superfluo y a lo frívolo, el body art, entre otros hedonismos difusos.

Maffesoli lanza entonces una hipótesis fundamental: de la misma forma que en la modernidad fue enaltecida la figura del hombre adulto, realizado, dueño de sí y de la naturaleza, hombre que ejerce además un principio de autoridad a través de prácticas prescriptivas; en la posmodernidad naciente, comienza a dominar el mito del puer aeternus -ese niño eterno- que en su juego permanente impone determinados modos de ser y de pensar. Es la presencia de Dionisos la que se extiende hoy en las grandes ciudades de occidente. Se revalora la importancia de lo festivo, de las apariencias y de la noción de destino. Se ve la existencia como una sucesión de instantes eternos. Es posible pensar incluso que si el trabajo, en su condición productiva y crucificadota, fue el signo de la época moderna, el nuevo modelo cultural será el juego, el quehacer lúdico y sus dimensiones de creatividad. Así, un sentimiento trágico-lúdico, una nueva e intensa sabiduría juvenil (como una especie de inconciente colectivo) parece retornar con fuerza a la vida diaria en la actualidad, que además escapa siempre a la lógica del deber ser. "La verdadera vida -afirma Maffesoli- está en todas partes salvo en las instituciones (...) no tiene proyectos puesto que no tiene objetivo preciso. De ahí el aspecto punzante de sus manifestaciones." (Maffesoli, 2001:16)

Adviene pues un reencantamiento del mundo, un nuevo tiempo mítico que se aprecia, por ejemplo, en la conjunción actual maravillosa del caballero de los cuentos y las leyendas medievales con la imagen del rayo láser. Si la modernidad privilegió el futuro, la época contemporánea (al igual que la decadencia romana o el renacimiento) privilegia el presente. La cultura occidental moderna se orienta hacia el futuro y el fundamento de su acción está en la exterioridad. Toda realización individual o social será pues del orden de lo ex-tenso, estará inscrita en proyectos predecibles racionalmente y su vocación será la trascendencia. De manera distinta hoy en día parece acentuarse la vivencia presente suspendida en la dimensión "destinal" del existir, que será del orden de lo in-tenso y cuya vocación será la inmanencia. En cualquier caso el afrontamiento del destino en la época contemporánea, no significa según Maffesoli una simple resignación, sino una confrontación y un furor de vivir de innegables efectos sociales: asumir el destino significa aquí la aceptación (trágica) del carácter paradójico de la vida en tanto que se incita a vivir las muertes, las "pequeñas muertes" de cada día y a integrar "homeopáticamente" la muerte a la vida, como la mejor manera de protegerse y crecer. Sucede entonces que la vida se vive "bajo la forma de avidez" en una intensa consumación, que busca ya no la presunta libertad absoluta y trascendente, sino esas pequeñas "libertades intersticiales" relativas y empíricas para ejercerlas diariamente. La connotación trágica está en la aceptación de la fatalidad y también en la incorporación -a veces paroxística- de determinadas 
prácticas del placer. De este modo, una turba peligrosa de nómadas y bárbaros parece haber penetrado los muros de la civilización moderna para fragmentarla irremediablemente.

Es así que el ser se torna acontecimiento que adviene a veces de manera violenta. De pronto por ejemplo, muchos jóvenes asumen una especie de exuberancia pagana que goza audazmente del presente vital invadido por la frescura del instante en toda su transitoriedad intensa. Rebeliones juveniles de goce multiforme que contravienen los designios de cualquier moralismo de la modernidad, sean de orden ideológico, económico o sexual. Aunado a esto, se vive actualmente una especie de co-presencia (Giddens) en la alteridad. Co-presencia de modulaciones e intensidad variables pero que engloba el ser en su devenir cotidiano: se acentúa la potencia de lo impersonal y sucede que, en muchos sentidos, uno es actuado más de lo que actúa por sí mismo. Se participa "mágicamente" de lo extraño en un ejercicio que rebasa particularidades individuales. Existimos, pues, en la medida en que mi prójimo, o lo otro social, me da existencia. Podrá ser rechazado o marginado aquel que no tenga de alguna forma el "olor del clan". Pero en cualquier caso, en esa intensidad y júbilo de tales situaciones trágicas, el individuo se realiza en un plus-ser.

Maffesoli argumenta también que libertad y necesidad se viven como tensión contradictorial (nunca superada por mecanismos dialéctico-dramático-sintético-calmantes). Es decir, se viven como una forma extraña de "armonía conflictiva" que conduce a la posibilidad de vivir un yo plural (uno se libera de sí mismo en el otro) que afirma la existencia sensible del aquí y el ahora. Se trata de una ética del instante: vivir a pesar de todo. Así la nueva concepción del tiempo social estaría marcada por el afrontamiento del destino y el retorno cíclico, entendido este último como necesidad vital de regeneración permanente. Se desea un destino intenso, sombrío, vital, fascinante. Se vive un eterno presente, un vitalismo más o menos conciente de sí mismo, pero que asegura la perduración del ser. Sucesión de momentos fijos cuya concatenación configura el flujo vital.

En este sentido es que, en contraste con la asunción de la razón y del futuro como valores de la modernidad, el mundo de hoy procura la imagen y el presente. La imagen precisamente porque actualiza y por eso retorna con fuerza en manifestaciones multiformes y asombrosas. Surgen resistencias a la temporalidad lineal, racional, útil e individualista de las actividades diurnas y se propende al instante eterno de la nocturnidad festiva, ritual, imaginativa y comunitaria. En el mundo de hoy la imagen se convierte en elemento esencial del lazo social. La imagen se torna omnipresente. Es el vector clave de una relación o vínculo social que implica emociones comunes, sentimientos y afectos puestos en juego en el ámbito público. La imagen cuestiona la noción racional de la historia o del tiempo del proyecto porque ella misma es del orden de la intuición, del flash, de la ocurrencia que acaece de improviso, del fulgor instantáneo.

En todo momento Maffesoli apela a una alegría del mundo expresada en la potencia del juego para configurar la vida presente efímera, intensa, ambivalente y que no pretende el dominio de la naturaleza, de la historia, de la sociedad o de sí misma. Una vida que detenta una actitud más comprensiva que explicativa y que implica mayor relativismo y cierto politeísmo de los valores. Se pondera un saber encarnado y pluralista. Ante la morosidad de lo instituido, emerge la alegría rebelde de lo instituyente. "Rebelión contra un artificialismo abstracto. Rebelión contra una sociedad de aburrimiento. Rebelión contra una seudo vida programada, que no deja más que poco espacio a la aventura y al simple placer de existir. Rebelión, recordémoslo, alternativa." (Maffesoli, Op.Cit.:179). Y rebelión también de lo imaginario. Maffesoli recupera en tal sentido la importancia del mundo de las apariencias, de esa sabiduría del parecer, de aquella irrupción de la imagen y exacerbación de lo sensible que se aprecia en las sociedades occidentales contemporáneas. Se alude también a la 
noción de máscara para referirse a la complejidad de papeles y voces de la persona actual inmersa en diversas situaciones cambiantes.

Por último Maffesoli habla de la "viscosidad" de lo social a través de la emergencia de co-identidades, redes y procesos de hibridación en el mundo de hoy. Se refiere a un éxtasis social que, comprendido en sentido estricto, implica un salir de sí para unirse, paradójicamente, a la alteridad. El sujeto moderno se diluye en un ser-juntos constante. Se valora también el proceso de feminización del mundo como vector fundamental de la creación de lo cotidiano. Tal feminización del mundo o fusión femenina, integra en una coincidentia oppositorum, los diferentes aspectos de lo humano en toda su ambivalencia o carácter paradójico: integra homeopáticamente un valor y su contrario. Relativiza el mundo, lo hace menos dogmático y más abierto. Ser ya no se comprende entonces sino como ser con el otro, o incluso, ser el otro, en un retorno a cierto erotismo cosmogónico. Al final Maffesoli subraya la noción de atracción apasionada para enfatizar la actitud vitalista y creadora en el mundo actual. En este tiempo del retorno de los pequeños dioses, resulta posible asumir una participación, en el sentido mágico, de las cosas, la gente, los lugares, para buscar al otro, tocarlo y hacer vida multiforme con él. Se trata de una participación mágica que se arraiga trágicamente en el momento presente, en el seno de la ciudad (vivida siempre como sucesión de lugares destacados). Se trata pues de un rejuvenecer el mundo, de re-imaginarlo en un decir sí (a pesar de todo) a la vida.

\section{VI.- UNA APROXIMACION A LO IMAGINARIO EN MAFFESOLI}

Para Enrique Carretero Pasín (2003a), la noción de imaginario social en la obra de Maffesoli remite al terreno de la teoría sociológica, incidiendo en cuatro aspectos determinantes en dicha consideración: el significado que entrega a la utopía, la problemática ligada a los ideales impuestos por la modernidad, el valor simbólico de las tribus en la postmodernidad y la legitimidad del orden social.

Por esta razón y a fin de seguir una secuencia con la anterior afirmación, se desarrollarán brevemente cada una de las categorías propuestas por Carretero y su relación con los planteamientos que hemos venido desarrollando en nuestro recorrido a través de la obra de Maffesoli, para intentar articular desde esta mirada una noción de Imaginario Social.

\section{Imaginario y utopía}

Maffesoli plantea la trascendencia de la ensoñación colectiva como movilizadora de la realidad social instituida. A partir de una revisión del papel asignado a lo imaginario en el pensamiento Freudiano, se reivindica la creatividad de lo imaginario como la de un ensueño que ha sido doblegado por una coercitiva racionalidad productiva. De ahí que la esencia de lo imaginario radica en una reacción contra la renuncia que impone una civilización represiva. Por esta razón, la vitalidad constituyente de lo imaginario se apoya sobre la efervescencia de una fantasía que rompe con la monotonía cotidiana y estimula la vida en sociedad.

Según Maffesoli, la utopía, contemplada desde la perspectiva de la forma y no desde el contenido, se revela como una manifestación propia de lo imaginario. Por medio de esta, se construiría un añorado futuro, recreándose en el pasado, renegando, así de su realidad cotidiana. De hecho para Maffesoli, tras todo proyecto revolucionario late siempre el germen de la utopía como medio de trascendencia 
de lo real y apertura a lo posible. Maffesoli insiste con esta tesis, cuando plantea que lo imaginario es aquello que dota de vigor a la utopía al movilizar la potencia social y cuestiona, de este modo, el orden establecido. Para Carretero (2005), esto se produce porque, en realidad, el ensueño, lo imaginario, el mito, canalizan las aspiraciones sociales y anhelos a través de una dimensión simbólica.

\section{Crítica de la modernidad e imaginario}

Maffesoli entiende que la modernidad ha impuesto un totalitarismo de la razón que reduce la realidad a criterios de utilidad y cálculo, sustituyendo, a través de un proceso de aparente desmitologización, al mito por el número. Así, de esta forma, la racionalidad moderna sería el asidero sobre el que descansaría la consolidación del ideal productivo y el mito del progreso. A través de ella, la heterogeneidad y singularidad de la realidad se someten a un perverso principio de equivalencia generalizada que concibe lo real como aquello reductible a un preestablecido esquema racional y que, en consecuencia, reprime la diferencia. En síntesis, Maffesoli trata de mostrar cómo la racionalidad científica es un elemento constitutivo de la dominación social. Asimismo, esta racionalidad abstracta, cuantitativa y formal, característica de la modernidad resultaría estéril al tratar de descifrar aquellos aspectos de la vida social irreductibles a este excluyente modelo de racionalidad. De ahí, el llamado en elogio de la razón sensible (1997) hacia un raciovitalismo, a una razón sensible, que redescubra la analogía y la metáfora como vías de conocimiento capaces de desentrañar toda la riqueza de lo social.

Mas aún, Maffesoli enfatiza que si la modernidad estableciera una lógica caracterizada por una monovalencia de lo racional en la que el mito y lo imaginario quedaran proscritos de la experiencia social, la cultura postmoderna, testimonia el valor y la eficacia social de éstos, realza aquello que precisamente ha sido excluido por la programática moderna; insinuando, en suma, un paradigma estético de cultura.

\section{Lo imaginario como configurador de la socialité}

En el pensamiento de Maffesoli se encuentra la inquietud sociológica por comprender la naturaleza de novedosas y plurales expresiones comunitarias que afloran en el conjunto de la vida social. En ese sentido, la tesis de Durkhemim sobre el rol de la religión en la configuración de la integridad simbólica de la sociedad sirve como sustento teórico esclarecedor para estas manifestaciones. Su interés sociológico, radicaría en que son un testimonio de la saturación de la modernidad, con lo que ello implica: el descrédito de la categoría de sujeto y la necesidad de superación de una racionalización de la existencia.

Maffesoli, realza la importancia de la emoción vivida en común y del sentimiento compartido, proponiendo el paradigma tribal como diagnóstico nuclear de las sociedades postmodernas. Por medio de éste, se designarían unos modos de relación social de tipo empático que testimoniarían la crisis de un proyecto social en tensión de futuro y la vitalidad de un sentimiento de comunidad ligado a lo presente. La crisis del metarrelato moderno provocaría la efervescencia de aquello reprimido bajo éste, propiciaría la emergencia de un componente pulsional que se canalizaría y plasmaría en unas nuevas micro mitologías de las cuales cristalizaría un sentimiento de comunidad compartido, un ethos común que adopta una expresión propiamente pasional y emocional, a lo que Maffesoli denomina como paradigma estético de cultura. 
La modernidad había significado la consolidación de la noción de identidad del sujeto. No obstante, en la actualidad, esta categoría se encontraría en crisis con el surgimiento de formas de socialidad. Es lo que Maffesoli expresa como el deslizamiento desde la lógica de la identidad hasta la lógica de la identificación.

En este punto es donde el imaginario social entra en juego, puesto que las novedosas manifestaciones de socialidad obedecen, en última instancia a expresiones de agrupabilidad que adquieren consistencia en un imaginario común. Desde una perspectiva similar, debiera ser comprendida, según Maffesoli, la efervescencia de la imagen en la sociedad actual. La imagen realza su importancia en una cultura proxémica, en la que se otorga prioridad a lo comunitario sobre lo individual y a las pequeñas historias vividas frente a la gran historia. A través de ella, se alcanzaría un reconocimiento y una identificación comunitaria.

Maffesoli afirma que la omnipresencia de la imagen en la vida social nos remitiría a un imaginario, a una suerte de inmaterialidad, en donde la imagen adquiere una particular significación. Este mundo imaginario es el soporte sobre el que se solidifica un sentimiento de comunidad compartido. De ahí que la imagen se configure, como un sacramento generalizado que favorece la interacción social y propicia la vivencia comunitaria. A juicio de Maffesoli, podría hablarse incluso de una corporalidad espiritual albergada en el seno de la propia imagen, puesto que ésta dispone de la facultad de movilizar y fusionar las diferentes sensibilidades individuales. Por medio de ella, la materialidad expresa un sentido de congregación simbólica y, al mismo tiempo, el espíritu de la sociedad adquiere una forma material y concreta. Maffesoli lo expresa sintéticamente como saber epifanizar la materia y corporalizar el espíritu. Física mística de la socializad.

\section{La legitimación del orden social}

Maffesoli aborda la relación existente entre lo imaginario y los mecanismos de legitimación de la dominación social. El poder, según el autor, necesitaría revestirse de una aureola simbólica desde la cual germine una aceptación interiorizada del orden social por parte de los dominados que surja de su propia voluntad sin necesidad de recurrir al uso de una violencia externa sobre ellos. De esta forma, el poder invoca siempre a lo imaginario, al ámbito del deseo, del sentimiento, consiguiendo controlar la pasión común y compartida que caracteriza a toda forma de sociedad. En efecto, el grado de eficacia en la conservación del poder radicaría precisamente en su capacidad para administrar el imaginario colectivo de una sociedad.

Maffesoli denomina origen ecológico del poder a la apelación del poder al orden de lo mitológico. El orden social se funda, de este modo, en una cosmogonía de la que cristaliza una tradición y que consolida la vida de una sociedad. Así, se podría hablar de un fundamento religioso de todo poder político, o, en otras palabras, se puede afirmar que todo ejercicio de la política se sostiene en última instancia sobre la religión. Esta religiosidad de la que se nutre el poder es lo que permite explicar la servidumbre voluntaria de los individuos en la que se les hace creer a estos que la dominación en lugar de tal es un servicio prestado a la entidad gobernante, la cual, como contrapartida, procuraría la protección al cuerpo social.

En síntesis, el ejercicio de lo político reclama siempre una mitología fundadora y legitimadora que remite a lo religioso. El carácter de religiosidad de lo político radica en su eficacia para generar un sentimiento de comunidad compartido a través de la incitación a lo imaginario. En otras palabras, según Maffesoli, no hay política sin religión. 


\section{Hacia la noción de imaginario social en Maffesoli}

La relevancia sociológica que confiere Maffesoli al orden de lo imaginario se inscribe en una fecunda tradición en el campo de las ciencias sociales arraigada en Francia desde los años setenta del pasado siglo. Dicha tradición está especialmente preocupada por aplicar la concepción filosóficoantropológica de lo imaginario, pero que puede retrotraerse incluso al estudio de la naturaleza de la imaginación poética de Gaston Bachelard y a la formulación de los rasgos de la imaginación creadora del islamista Henry Corbin, a la comprensión sociológica de diferentes contextos de la vida social.

Michael Maffesoli, Georges Balandier, Pierre Sansot Raymond Ledrut o Alain Pessin entre otros, adscritos en mayor o menor medida a la Escuela de Grenoble, se han reapropiado de la noción de imaginario como soporte teórico destinado a la elaboración de un nuevo paradigma sociológico en el que se concede una singular trascendencia a la interpretación de los componentes míticos y simbólicos arraigados en la vida colectiva.

Siguiendo a Carretero (2003b), tratar de comprender los fenómenos sociales contemporáneos desde la perspectiva de los imaginarios, es reconocer, -parafraseando a Castoriadis-, que la historia de la humanidad es la historia del imaginario humano y de sus obras. Se trata entonces de una posibilidad plausible y pertinente, que reconoce en la acción práctica del ser humano (con otros y sobre el sí mismo), en la dinámica de lo instituido y lo instituyente, una dialéctica poiética de autocreación.

Los imaginarios sociales producen valores, las apreciaciones, los gustos, los ideales y las conductas de las personas que conforman una cultura. El imaginario será entendido a su vez que efecto de una compleja red de relaciones entre discursos y practicas sociales que interactúan con las individualidades.

Se conforma así una red de representaciones que atraviesan el conjunto de lo social, construcciones que se cristalizan en las muy diversas formas institucionales, con sus reglas y funcionamiento particular. Podríamos hablar aquí de ese punto de articulación entre lo subjetivo y lo social, ya que son los sujetos desde su posición relativa a un momento histórico, a una ubicación social y al propio psiquismo que desarrollarán, perpetuarán y modificarán continuamente esas construcciones de sentido.

A la misma vez ese imaginario es el que construye a los seres humanos como seres sociales, en la integración de representaciones, en gran medida a un nivel inconsciente. Castoriadis señala que esta interiorización no es en modo alguno superficial porque los modos de pensamiento y acción, las normas y valores y, finalmente, la identidad misma del individuo dependen de ella. Dicho proceso tiene lugar a lo largo de toda la vida de cada sujeto, careciendo de principio o fin para la red social.

En el trabajo de Maffesoli, esta preponderancia atribuida a lo imaginario se conjuga, además con una notoria influencian de la sociología francesa Durkheimiana, gestada en Las formas elementales de la vida religiosa. En este contexto, y a manera de síntesis, la originalidad de la aportación sociológica de Maffesoli en torno a lo imaginario puede estructurarse en la siguiente triada:

- La fundamentación epistemológica de una sociología de la vida cotidiana que focaliza su atención sobre lo banal, lo efímero, lo frívolo, en la que lo imaginario, incluido en el registro de lo simbólico juega un papel nuclear.

- La utilización del orden de lo imaginario en la propuesta del tribalismo como marco referencial encargado de disolver la lógica específica de una variada gama de fenómenos sociales emergentes en las sociedades contemporáneas. En esta perspectiva, lo imaginario es 
contemplado como un continente de acogida que proporciona una identidad social, como un espacio que conforma una congregación comunitaria en torno a emblemas simbólicos.

- La inscripción de la noción de imaginario en el debate teórico contemporáneo centrado en torno a la modernidad. Lo imaginario, en este contexto facilitaría un reencantamiento de una existencia social previamente reificada por una unidimensional racionalidad moderna, edificando potenciales posibilidades de realidad, utopías intersticiales en palabras de Maffesoli, que transfigurarían la desencantada realidad cotidiana.

\section{Referencias}

Carretero, E. (2002). Imaginario social y crítica ideológica. Servicio de Publicaciones e Intercambio Científico de la Universidad de Santiago de Compostela.

Carretero, E. (2003a). La noción de imaginario social en Michel Maffesoli. Revista Española de investigaciones sociológicas, № 104 (octubre-diciembre): 199-209.

Carretero, E. (2003b). La radicalidad de lo imaginario en C. Castoriadis. Anthropos. № 198: 95-106.

Carretero, E. (2005). Imaginarios y utopía. Athenea Digital № 7 . http://antalya.uab.es/atheneal. Extraído el 23 de Noviembre del 2005.

Chuaqui, Laura. (2004). Conociendo a Michel Maffesoli. En www.umce.cl/ dialogos/dialogos educativos n1 articulo 06.pdf. Extraído el 20 de noviembre del 2005.

Diario La Nación (2005). Estamos en la era de los nómades y las tribus, dice Maffesoli. http://www.lanacion.com.ar/archivo/nota.asp?nota id=734590\&origen=acumulado\&acumula do id=Extraído el de diciembre de 2005.

Maffesoli, M. (1990). El tiempo de las tribus: el declive del individualismo en las sociedades de masas. Barcelona: Icaria.

Maffesoli, M. (1993). El Conocimiento Ordinario. Compendio de Sociología. México: Fondo de Cultura Económica.

Maffesoli M. (1996). De la orgía. Una aproximación sociológica. Barcelona: Ariel.

Maffesoli, M. (1997). Elogio de la razón sensible: una visión intuitiva del mundo contemporáneo, Barcelona: Paidós.

Maffesoli, M. (2001). El instante eterno. El retorno de lo trágico en las sociedades posmodernas. Buenos Aires: Paidós.

Maffesoli, M. (2003). El Imaginario Social. Anthropos, № 198: 149-153.

Platón (1981). El Banquete, Fedón y Fedro. Barcelona: Guadarrama.

Real Academia de la Lengua Española (2005): http://www.rae.es/. Extraído el 18 de diciembre de 2005. 


\section{Formato de citación}

Cassián, Nizaiá; Escobar, Ma. Gisela; Espinoza, Ricardo; García, Raúl; Holzknecht, Martín y Jiménez, Carolina. (2006). Imaginario Social: Una aproximación desde la obra de Michel Maffesoli. Athenea Digital, 9. Disponible en http://antalya.uab.es/athenea/num9/Cassian.pdf.

Nizaiá Cassián, Ma. Gisela Escobar, Ricardo Espinoza, Raúl García, Martín Holzknecht y Carolina Jiménez son doctorandos del Programa de Psicología Social de la Universitat Autónoma de Barcelona.

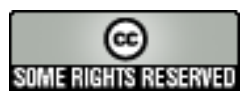

Este texto está protegido por una licencia $\underline{\text { Creative Commons. }}$

Usted es libre de copiar, distribuir y comunicar públicamente la obra bajo las siguientes condiciones:

Reconocimiento: Debe reconocer y citar al autor original.

No comercial. No puede utilizar esta obra para fines comerciales.

Sin obras derivadas. No se puede alterar, transformar, o generar una obra derivada a partir de esta obra.

\section{$\underline{\text { Resumen de licencia }}$}

$\underline{\text { Texto completo de la licencia }}$ 